\title{
New occurrences of Belonostomus (Teleostomorpha: Aspidorhynchidae) from the Late Cretaceous of the North American Gulf Coastal Plain, USA
}

\author{
Nathan E. Van Vranken, Christopher Fielitz, and Jun A. Ebersole
}

\begin{abstract}
This research reinforces the poorly documented Cretaceous record of the aspidorhynchid fish Belonostomus found in the North American Gulf Coastal Plain. This unique fish has gone mostly unnoticed in fossil collections due to the heightened diversity and popularity of other Cretaceous teleosts. Six new specimens are documented from various fossil sites in Texas, Mississippi, and Alabama. Most of these fossil localities have not produced aspidorhynchid material until now and help bridge the gap in records between the Lower and Upper Cretaceous stratigraphic records of the North American continent. The inclusion of these new Belonostomus records also helps to further our understanding of this enigmatic fish.
\end{abstract}

Nathan E. Van Vranken. Division of STEM, Potomac State College, 101 Fort Ave, Keyser, West Virginia, 26762, USA. nvanvranken@sbcglobal.net

Christopher Fielitz. Biology Department, Emory \& Henry College, P.O. Box 947, Emory, Virginia 24327, USA. cfielitz@ehc.edu

Jun A. Ebersole. McWane Science Center, 200 19th St N, Birmingham, Alabama, 35203, USA.

Jebersole@mcwane.org

Keywords: Cretaceous; Aspidorhynchiformes; Gulf Coast; Alabama; Mississippi; Texas

Submission: 19 March 2019. Acceptance: 16 August. 2019

\section{INTRODUCTION}

Belonostomus is an apidorhynchyid teleosteomorph fish found within marine paleocommunities of the llate Mesozoic (Arratia, 2001). It is a small fish, measuring $31 \mathrm{~cm}$ on average (Brito, 1994; Ebert, 2014). This aspidorhynchid fish most likely consumed planktonics or other small fish (Wainwright and Barton, 1995; Cavin, 2002; Friedman, 2009; Kogan and Licht, 2013) and were probably a prey item for larger fishes and marine reptiles that commonly accompany the remains at fossil localities.

Van Vranken, Nathan E., Fielitz, Christopher, and Ebersole, Jun A. 2019. New occurrences of Belonostomus (Teleostomorpha: Aspidorhynchidae) from the Late Cretaceous of the North American Gulf Coastal Plain, USA. Palaeontologia Electronica 22.3.58 1-11. https://doi.org/10.26879/983

palaeo-electronica.org/content/2019/2725-new-belonostomus-record

Copyright: September 2019 Paleontological Society.

This is an open access article distributed under the terms of Attribution-NonCommercial-ShareAlike 4.0 International (CC BY-NC-SA 4.0 ), which permits users to copy and redistribute the material in any medium or format, provided it is not used for commercial purposes and the original author and source are credited, with indications if any changes are made.

creativecommons.org/licenses/by-nc-sa/4.0/ 
The Aspidorhynchidae consist of the genera Aspidorhynchus, Belonostomus, Vinctifer, Richmondichthys, Pseudovinctifer, and Jonoichthys (Brito, 1997; Arratia, 2001; 2013; Gouiric-Cavalli, 2015; Nelson et al 2016; Cantalice et al., 2018). A seventh genus, Diphyodus (Lambe, 1902) is synonymous with Belonostomus (Estes, 1964). Aspidorhynchidae are related to the Pachycormiformes (Lopez-Arbarello and Sferco, 2018). The stratigraphic range of the genus is well documented. The earliest record for Belonostomus is the type specimen, B. tenuirostris (Agassiz, 1833), which was derived from the Late Jurassic (Tithonian) at the Solnhofen Lagerstätten in Europe. The last occurance of Belonostomus extends until shortly after the K-Pg extinction event in the Late Paleocene (Tiffian) in North America, possibly due to a large shift in the paleoenvironments during the regression of the Western Interior Seaway (Bryant, 1987; Brito, 1997; Ebert, 2014). Six new occurrences of Belonostomus are reported from the North American Gulf Coastal Plain. The inclusion of these new specimens helps further document the biogeographic and biostratigraphic range of Belonostomus in North America.

\section{METHODS AND MATERIALS}

The fossils described in this study, including those collected by the first author in Texas (Figure 1 ), were collected as float and then placed in the local, publicly accessible collections listed below. The first author and third authors prepared the specimens for study using a small steel pin to clean excess matrix from the elements and made repairs to the broken segments using super glue adhesive. The North American map (Figure 2) and stratigraphic placement (Figure 3) were compiled using Scott et al. (2003) and observations by the authors. We follow Arratia (2001) for higher-level taxonomic rankings for the fossils.

\section{INSTITUTIONAL ABBREVIATIONS}

ALMNH: Alabama Museum of Natural History, Tuscaloosa, USA; FHSM: Sternberg Museum of Natural History, Hays, Kansas, USA; KUVP: University of Kansas Natural History Museum, Lawrence, USA; MMNS: Mississippi Museum of Natural Science, Jackson, USA; SMU: Southern Methodist University, Dallas, Texas, USA; TMM (= UTBEG): Texas Memorial Museum, Austin, USA.

\section{SYSTEMATIC PALEONTOLOGY}

Division TELEOSTOMORPHA Arratia, 2001

Subdivision ASPIDORHYNCHEI Nelson et al., 2016

Order ASPIDORHYNCHIFORMES Bleeker, 1859 Family ASPIDORHYCHIDAE Nicholson and Lydekker, 1889

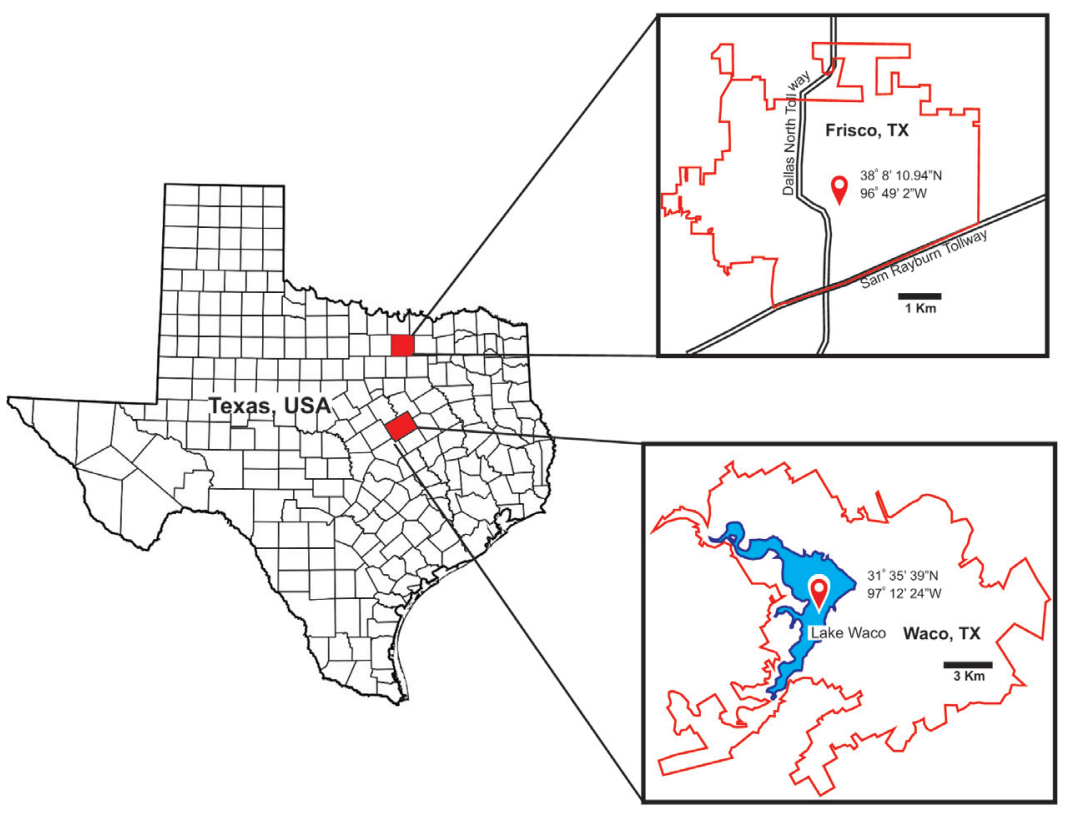

FIGURE 1. A locality map showing the counties in Texas, USA where the three new Belonostomus fossils were collected. 


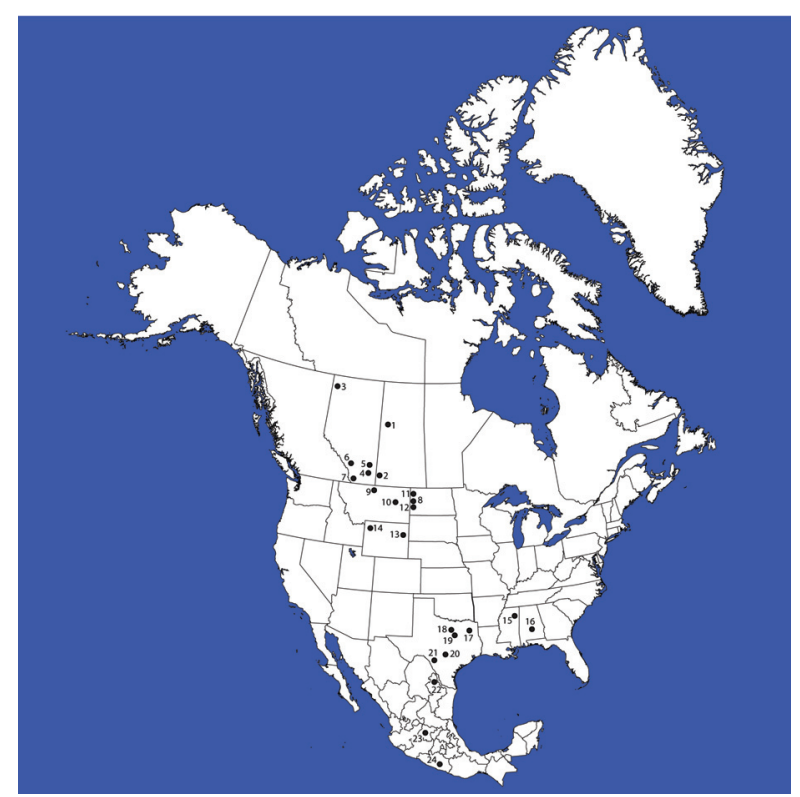

FIGURE 2. An expanded map showing all known localities in North America that have produced Belonostomus fossils. 1. Ashville Formation, Saskatchewan, Canada. 2. Frenchman Formation, Saskatchewan, Canada. 3. Kaskapau Formation, Alberta, Canada. 4. Foremost and Oldman formations, Alberta, Canada. 5. Dinosaur Park Formation, Alberta, Canada. 6. Horseshoe Canyon, Alberta, Canada 7. St. Mary River Formation, Alberta, Canada. 8. Tongue River Formation, North Dakota, USA.9. Judith River Formation, Montana, USA. 10. Hell Creek Formation, Montana, USA 11. Judith River Formation, North Dakota, USA 12. Hell Creek Formation, North Dakota, USA. 13. Lance Formation, Wyoming, USA. 14. Mesa Verde Formation, Wyoming, USA, 15. Prairie Bluff Chalk, Mississippi, USA. 16. Tombigbee Sand Member of the Eutaw Formation, Alabama, USA 17. Paluxy Formation, Texas, USA 18. Austin Chalk Formation, Texas, USA 19. Del Rio Formation, Texas, USA, 20. Eagle Ford Formation, Texas, USA. 21. Agua Nueva Formation, Nuevo Leon, México. 22. Tlayua Formation, Puebla, México. 23. Cerro de la Virgen Formation, Oaxaca, México.

\section{Genus BELONOSTOMUS Agassiz, 1843 Belonostomus sp.}

Referred material. SMU 77675. Left and right premaxillae (Figure 4). Collected from the contact between the Eagle Ford Shale and Austin Chalk in Collin County, Texas, USA, Upper Cretaceous (Figure 1).

Description. The left and right premaxillae are slender bones that fuse, forming a ventral $V$ shaped trough. A thin bone that could be the vomer is preserved in the trough (Estes, 1964). Together, the premaxillae measure $179.80 \mathrm{~mm}$ in length. It closely resembles UTBEG 31051-39 and Belonostomus longirostris (Woodward, 1894; Bardack,
1968; Estes, 1964). The teeth on the specimen are small, slightly recurved, and increase in size posteriorly.

Referred material. SMU 77676, partial predentary (Figure 5). Collected from the Cenomanian Del Rio Formation in McLennan County, Texas, USA, Upper Cretaceous (Figure 1).

Description. The partially preserved predentary measures $46 \mathrm{~mm}$ and resembles FHSM VP 17431 (Everhart, 2009). The left and right dentaries are fused and form a predentary symphysis, which articulates with the predentary. In ventral aspect, the symphysis sits within a small recess, and the two dentaries interdigitate to form a crosshatched pattern with small bulbous ridges. This may be a new feature for Belonostomus. The teeth are consistent to descriptions found in Woodward (1894) and Estes (1964) and other specimens discussed in this report.

Referred material. SMU 77677 , a partial rostrum (Figure 6). Collected from the contact between the Eagle Ford Shale and Austin Chalk in Collin County, Texas, USA, Upper Cretaceous (Figure 1). Description. Measures $54.5 \mathrm{~mm}$ from anteriormost point to the base. In cross section the element looks like an inverted "U" with both sides fused medially, the fusion is mostly obscured by matrix. The overall morphology closely resembles Belonostomus longirostris (Brito and Suarez, 2003). In ventral view, the teeth are closely spaced and are situated within a canal with a thin layer of bone, which covers at least one half of each tooth. Most of the teeth were not preserved.

Referred material. ALMNH 1994.24.15, a partial premaxilla (Figure 7). Collected from the upper Santonian Tombigbee Sand Member of the Eutaw Formation in Montgomery County, Alabama, USA, Upper Cretaceous.

Description. Measures $4.1 \mathrm{~mm}$ in greatest anteroposterior length and has a greatest width of $3 \mathrm{~mm}$ at its posterior end. Neither the anterior or posterior ends of ALMNH 1994.24.15 are preserved. In dorsal view, this premaxilla has straight lateral edges that have a slight medial taper anteriorly. The element is ornamented with a series of strong parallel striations that extend the length of the premaxilla and cover the dorsal and lateral edges. These striations occasionally intersect along the dorsal margin. In ventral view, a shallow sulcus extends medially along the entire length of the premaxilla. This sulcus is V-shaped in posterior view, and it becomes gradually shallower towards the anterior end. Positioned on each lateral side of this sulcus is a single row of minute, tightly packed, alveoli 


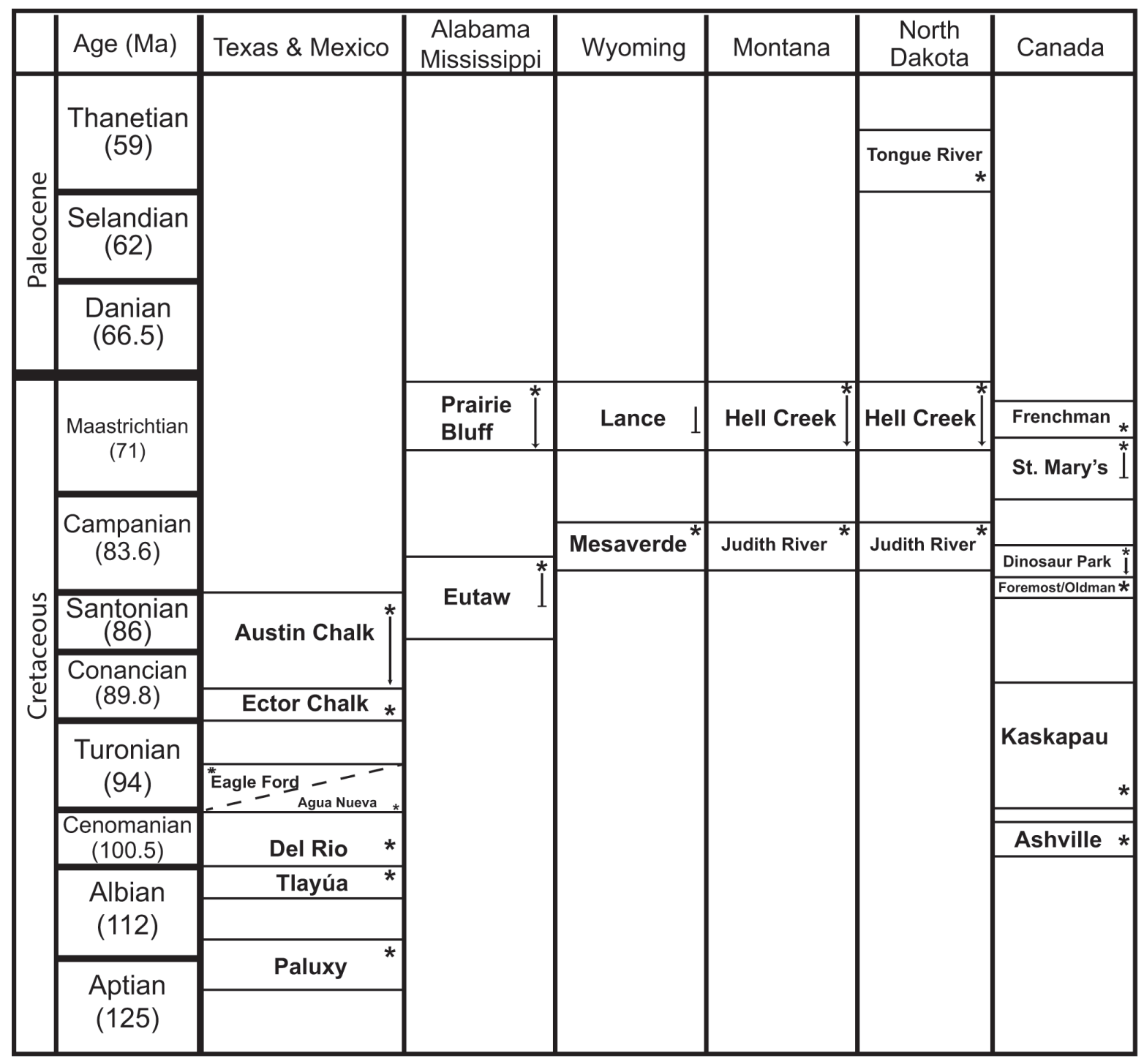

FIGURE 3. A correlated stratigraphic column representing formations in the North American Gulf Coastal Plain where Belonostomus fossils can be found. The stars represent where in the section Belonostomus fossils have been documented. The line indicates how deep into section they have been observed (modified from Scott et al., 2003).

(Figure 7.3). No teeth are preserved on this specimen, but the tooth rows extend the entire length of the element.

Referred material. MMNS 3152, rostrum and premaxillae (Figure 8). Collected from the Maastrichtian Prairie Bluff Chalk in Oktibbeha County, Mississippi, USA, Upper Cretaceous.

Description. The specimen represents the rostrum and premaxillae that are fused with no sutures to mark the boundaries between the elements. The specimen measures $176 \mathrm{~mm}$ long with the posterior $31 \mathrm{~mm}$ of the element possessing teeth. Ventrally, a suture marks the boundary between the left and right premaxilla. Each premaxilla has a single, large tooth positioned medially within a deep ventral excavation. Rows of smaller teeth reside on a ridge that flanks the medial tooth. Overall, the architecture of the teeth and premaxilla is similar to the other specimens and still consistent with most Belonostomus species except for $B$. helgandicus and "Belonostomus sp. 3" (Brito. 1997). Small teeth are present between the gaps where larger teeth would have been and disappear at least onethird from the anterior tip of the element.

Referred material. ALMNH VP 1994.31.112, a partial dentary (Figure 9). Collected from the upper Santonian Tombigbee Sand Member of the Eutaw 

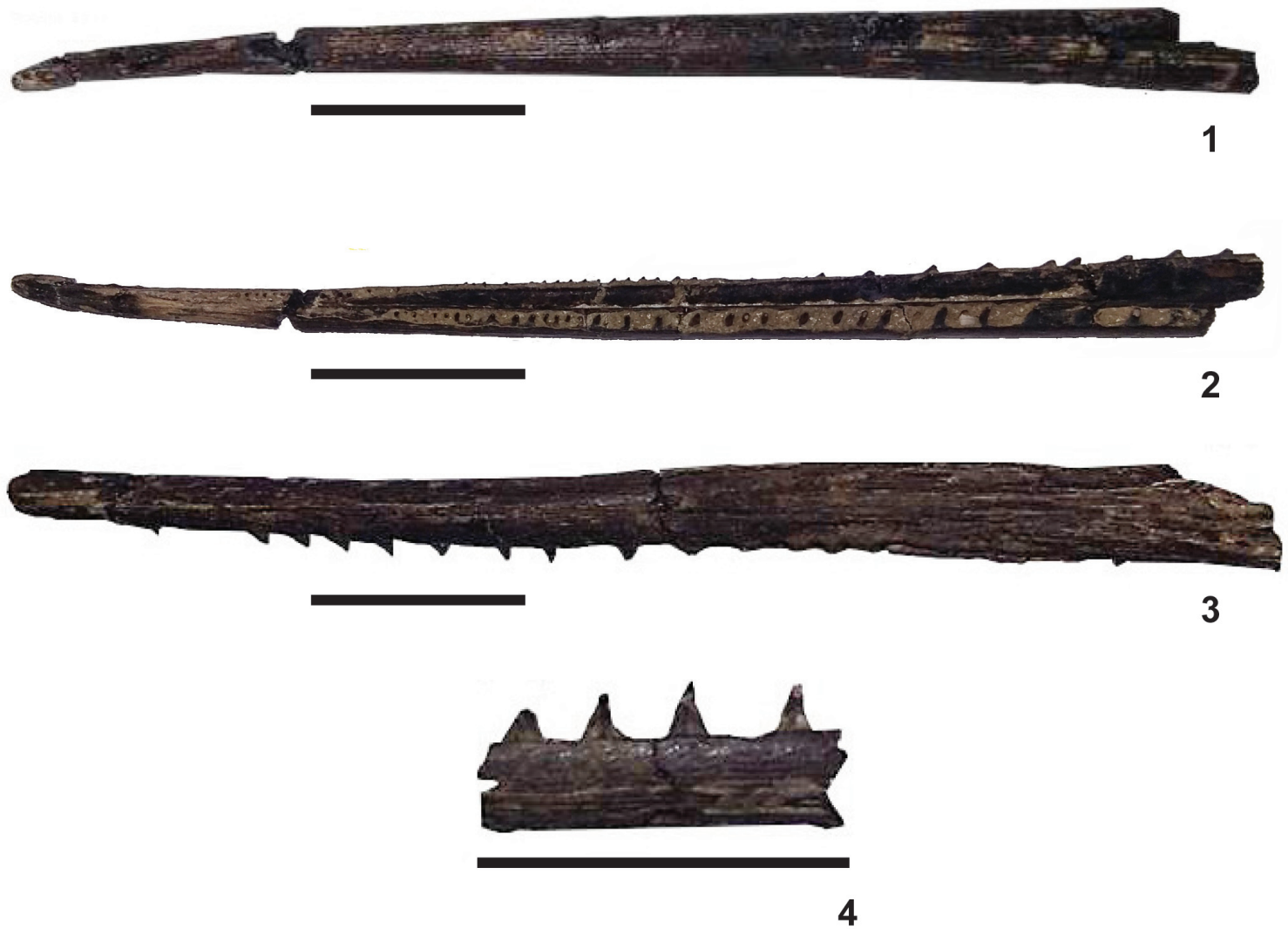

FIGURE 4. Belonostomus sp. SMU 77675. Fused left and right premaxillae. 1, dorsal view; 2, ventral view; 3, left lateral view; 4, close up of the teeth in lateral view. Scale bars equal $10 \mathrm{~mm}$.
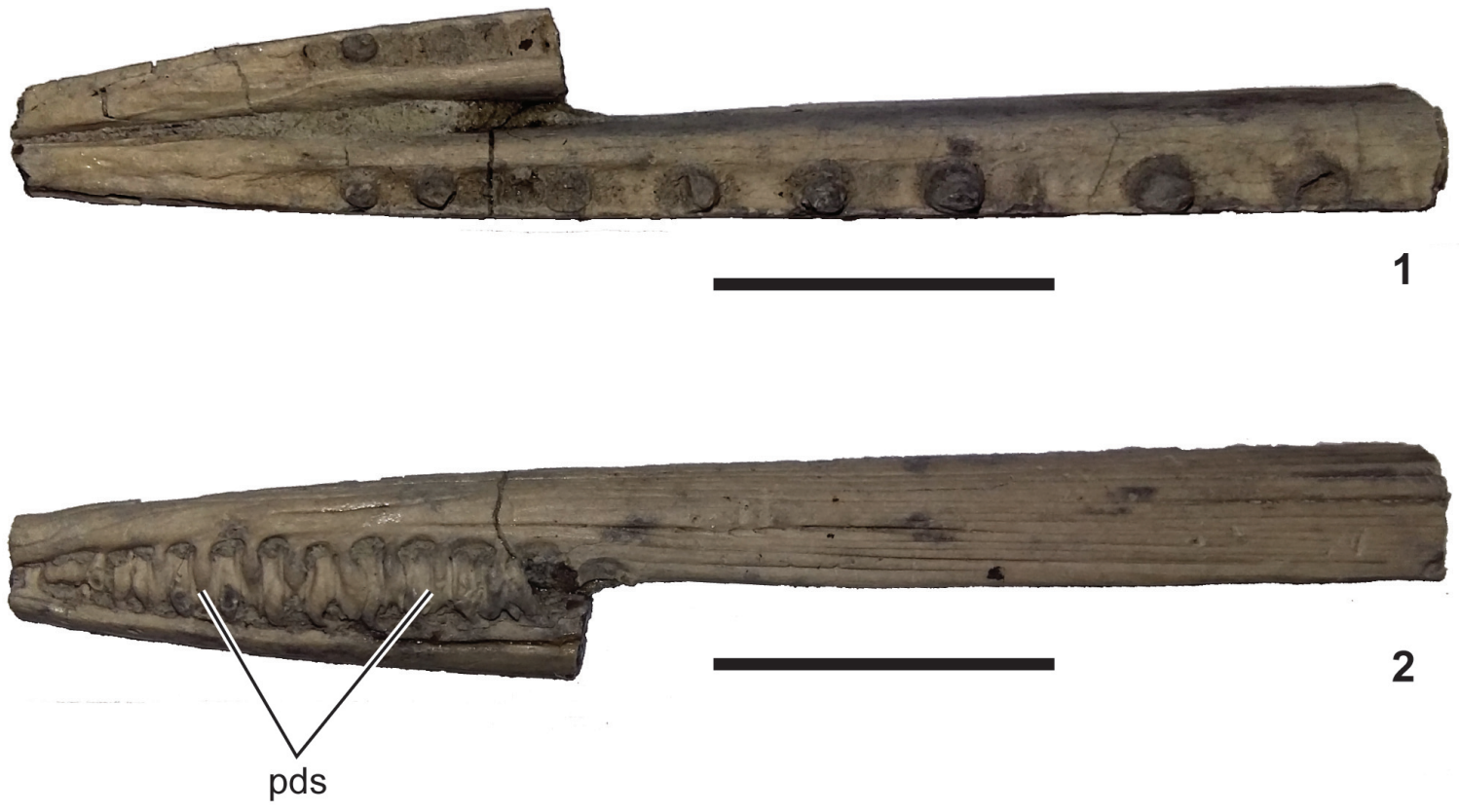

FIGURE 5. Belonostomus sp. SMU 77676. Partial predentary. 1, ventral view; 2, dorsal view. Abbreviation: pds: predentary symphysis. Scale bars equal $10 \mathrm{~mm}$. 

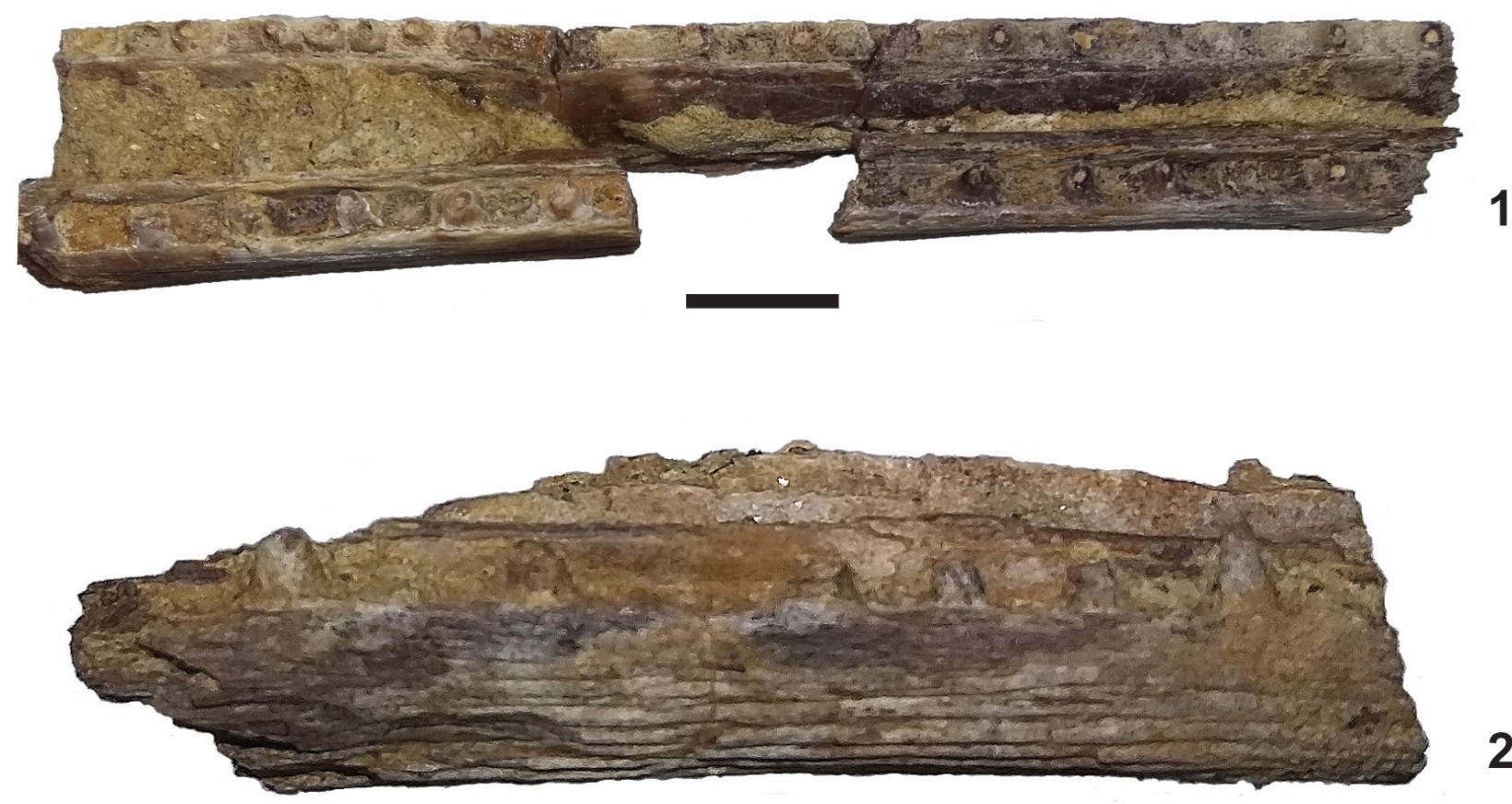

FIGURE 6. Belonostomus sp. SMU 77677. 1, ventral view; 2, lateral view. Scale bars equal $10 \mathrm{~mm}$.
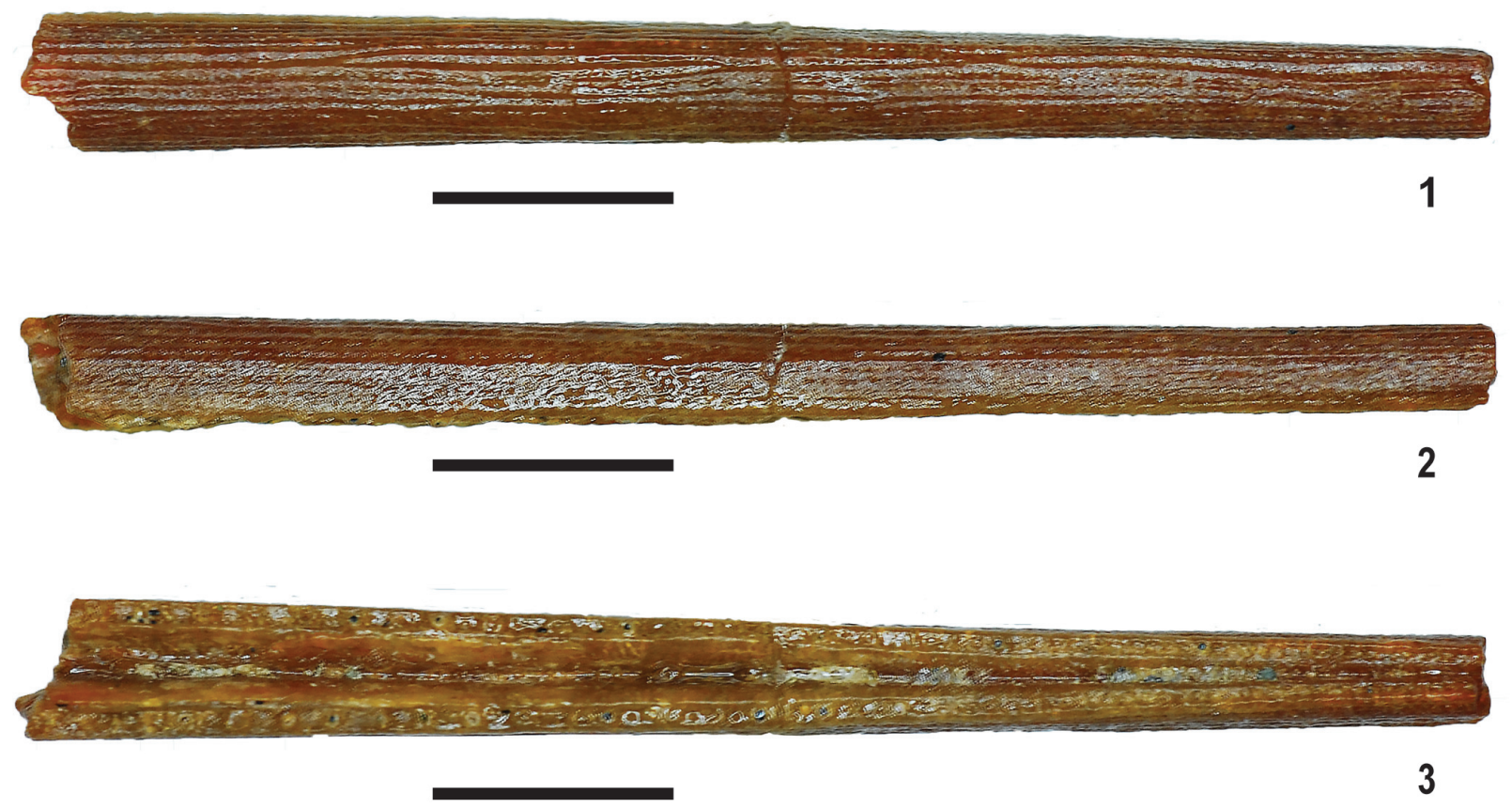

FIGURE 7. Belonostomus sp. ALMNH 1994.24.15 1, dorsal view; 2, right lateral view; and 3, ventral view. Scale bars equal $5 \mathrm{~mm}$. 

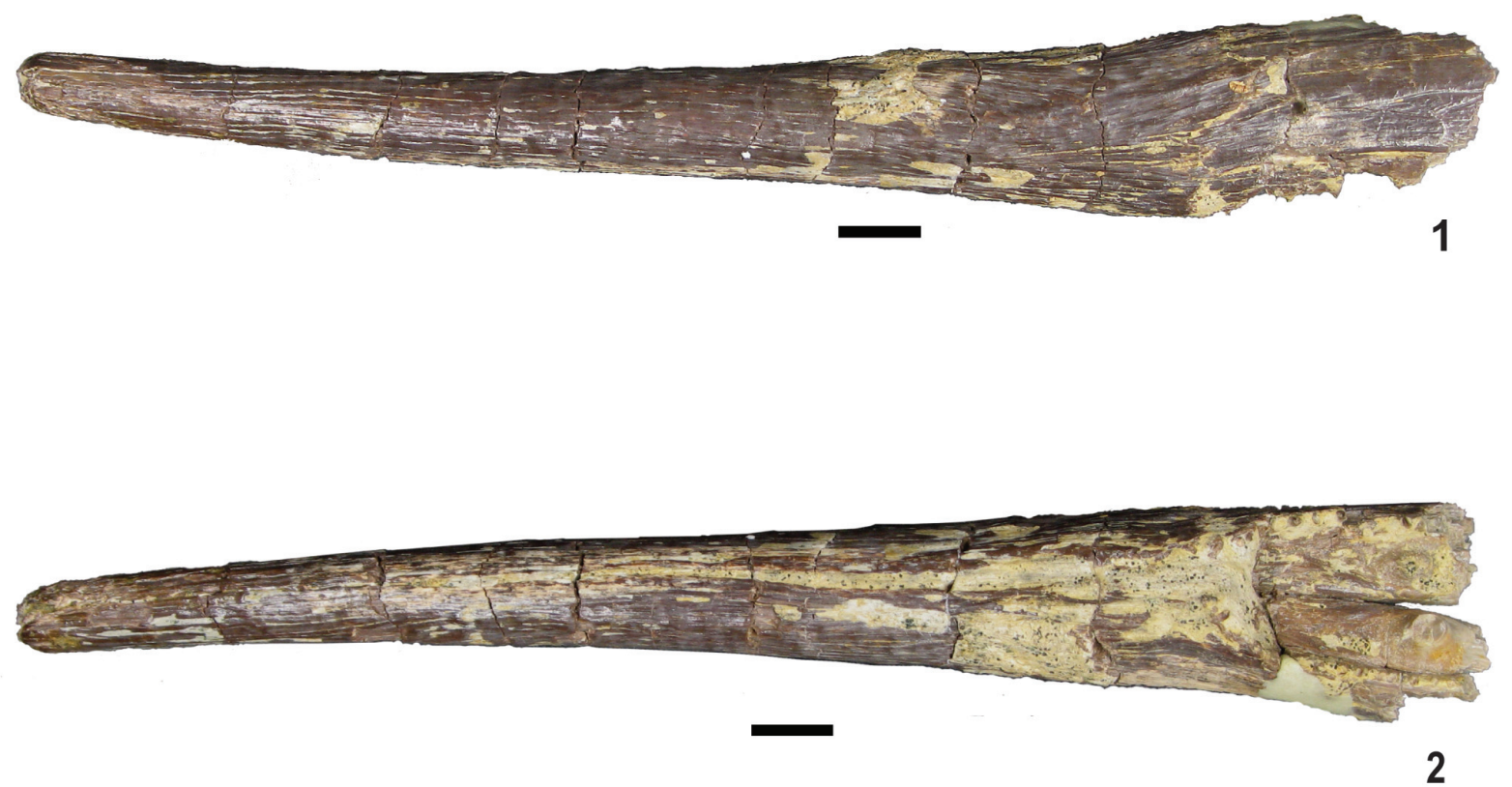

FIGURE 8. Belonostomus sp. MMNS 3152. Rostrum and premaxillae. 1, left lateral view. Anterior to the left. 2, ventral view. Scale bar equal $10 \mathrm{~mm}$.

Formation in Montgomery County, Alabama, USA, Upper Cretaceous.

Description. The element measures $21 \mathrm{~mm}$ in greatest anteroposterior length, and nearly $4 \mathrm{~mm}$ in greatest labiolingual thickness. The oral surface of the dentary is covered with a dense tooth patch of irregularly placed sub-circular teeth of various diameters. The crown on the individual teeth is rounded and lacks a distinct cusp. A pronounced ridge extends medially across the length of the labial and lingual faces of the dentary. The ventral face is composed of a thin crest that also extends the length of the element and forms a distinct Tshaped outline in profile view.

\section{DISCUSSION AND CONCLUSIONS}

Fossils that have been identified as Belonostomus have been collected from various units that range from the Albian to the Maastrichtian in the North American Gulf Coastal Plain (Figures 2, 3).

Mexico-Belonostomus specimens are reported mainly from Lower Cretaceous formations. Belonostomus ornatus was the first member of the genus described in Mexico. It was recovered from the Lower Cretaceous Berriasian (Sabinal Formation?) rocks of Cerro de la Virgen, Tlaxiaco in Oaxaca State (Felix, 1891; Russell, 1988) (Figure 3). Vinctifer sp. and Belonostomus sp. specimens have been recovered from the late Albian Tlayúa Formation at the Tlayúa quarry which is located in the state of Puebla (Espinosa-Arrubarrena and Alvarado-Ortega, 2010) (Figures 2, 3). The youngest record of Belonostomus sp. in Mexico comes from the Vallecillos quarry of the Lower Turonian Agua Nueva Formation (Giersch et al., 2010).

Texas, USA-The occurrence of Belonostomus ranges from the Upper Aptian to the end of the Santonian. Bardack (1968) reported on UTBEG 31051-49 and TMM 40092-23, both from the Austin Chalk (Coniacian to early Campanian). Thurmond (1974) then reported on SMU 62133 from the Lower Cretaceous Paluxy Formation in Mills County, near the city of Priddy. The specimens SMU 77675, SMU 77676, and SMU 77677 fill in some of the gaps of the state. The authors are unaware of any Belonostomus collected elsewhere in the state.

Mississippi, USA-The robust aspidorhynchiform rostrum, MMNS 3152, was found in the Upper Cretaceous (Maastrichtian) Prairie Bluff Chalk in Oktibbeha County (Figures 2, 3). It appears morphologically similar to both SMU 77675 and SMU 77676, but is much larger in size. This specimen, suggested to be Belonostomus, would be the youngest occurrence of the genus in the Gulf Coastal Plain and is the largest specimens reported in the area (Figures 2, 3).

Alabama, USA-Whetstone (1978), and later Schultze et al. (1982) and Russell (1988), reported 

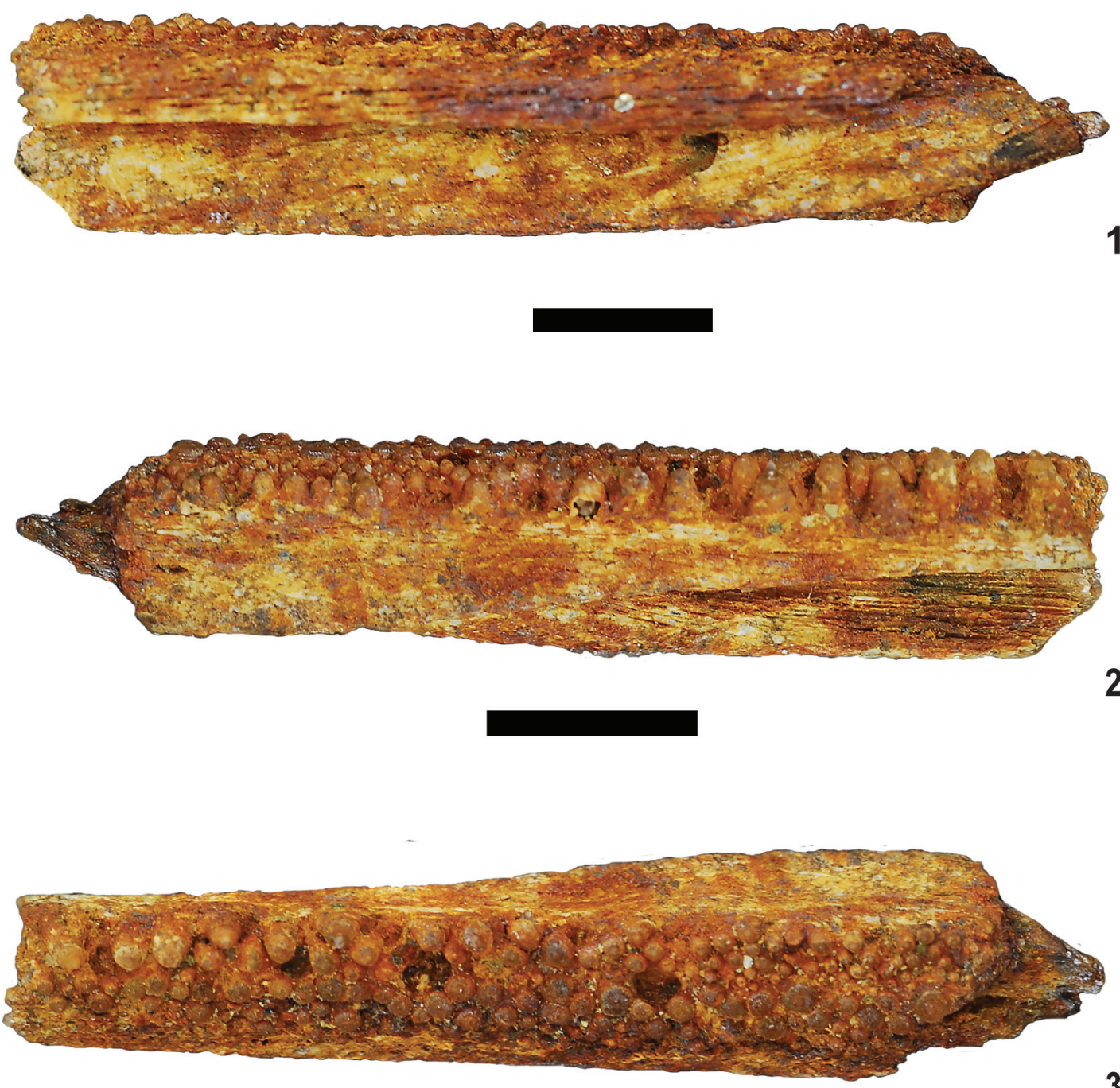

FIGURE 9. Belonostomus sp. ALMNH 1994.31.112. 1, lateral view; 2, medial view; 3, dorsal view. Scale bars equal 5 $\mathrm{mm}$.

the first Belonostomus specimen from Alabama, KUVP 36120. Collected from the Tombigbee Sand Member of the Eutaw Formation at site AMg-2 in Montgomery County, this specimen was originally reported to be Campanian in age (Figures 2, 3). However, later investigations of this unit showed that the exposed Tombigbee Sand at site AMg-2 instead falls within the upper Santonian (Puckett, 2005; Prieto-Marquez et al., 2016). Two additional specimens were later collected from the same unit and locality, ALMNH 1994.24.15 and ALMNH VP 1994.31.112, the former being first reported by Schein and Lewis (2007).
Belonostomus and aspidorhynchiform specimens have also been reported in North American localities outside of the Gulf Coastal Plain and range between the Lower Cretaceous to lower Paleocene (Figure 2, Figure 3). These include the Ashville, Kaskapau, Dinosaur Park, St. Marys, and Milk River formations in Canada; Judith River and Hell Creek Formations in Montana; Tongue River Formation in North Dakota; Mesa Verde and Lance formations in Wyoming and possibly the Kiowa and Niobrara formations in Kansas (Fox, 1984; Bryant, 1987; Russell, 1988; Ping et al., 2001; Pearson et al., 2002; DeMar and Breithaupt, 2006; Shimada and Fielitz, 2006; Everhart, 2009; Murray and 
Cook, 2016; Brinkman et al., 2017). The inclusion of the six new specimens reported here adds to the stratigraphic and paleobiogeographic records of Belonostomus in North America.

Due to the large biogeographic and stratigraphic range for the genus, the authors propose that the Gulf Coastal specimens could represent a different species than Belonostomus 'longirostris', which is commonly used in the literature and different than the unnamed aspidorhynchiform specimen, FHSM VP 17431 from Kansas. This could be explained by vicariance, which is consistent with most known dispersals of bony fishes (Heads, 2005; Cavin, 2008). However, naming a new species is not the focus of this project and will be left as a future contribution.

\section{ACKNOWLEDGEMENTS}

The authors would like to express gratitude toward the following people who helped develop this project into publication. B. Durr, W. Kirpach, and $\mathrm{R}$. Morin who were instrumental for allowing the authors to work on their collected specimens and bring light to the new data. Thanks to D. Winkler (SMU), J.C. Sagebiel (TMM), D.J. Ehret (NJSM), G. Phillips (MMNS), and D. Miao (KU) for granting access to the collections housed in their respective institutions. M. Friedman (UofM), J-P. Hodnett (M-NCPPC), G. Arratia (KU), and the anonymous reviewers for insightful commentary dealing with this project.

\section{REFERENCES}

Agassiz, L. 1843. Recherches sur les Poissons Fossiles. Petitpierre, Neuchâtel and Soleure.

Bardack, D. 1968. Belonostomus sp., the first holostean from the Austin Chalk (Cretaceous) of Texas. Journal of Paleontology, 4:1307-1309.

Arratia, G. 2001. The sister-group of Teleostei: consensus and disagreements. Journal of Vertebrate Paleontology, 21:767-773. https://doi.org/10.1671/02724634(2001)021[0767:tsgotc]2.0.co;2

Arratia, G. 2013. Morphology, taxonomy, and phylogeny of Triassic pholidophorid fishes (Actinopterygii, Teleostei). Journal of Vertebrate Paleontology 33 (Suppl. 1):1-138. https:// doi.org/10.1080/02724634.2013.835642

Brinkman, D.B., Neuman, A.G., and Divay, J. 2017. Non-marine fish of the late Santonian Milk River Formation of Alberta, Canada-evidence from vertebrate microfossil localities. Vertebrate Anatomy Morphology Palaeontology, 3:7-46. https://doi.org/10.18435/b5pp41

Brito, P.M. 1997. Révision des Aspidorhynchidae (Pisces, Actinopterygii) du Mésozoïque: ostéologie, relations phylogénétiques, données environnementales et biogéographiques. Geodiversitas, 19:681-772.

Brito, P.M. and Suarez, M.E. 2003. Late Cretaceous Belonostomus (Pisces, Actinopterygii, Aspidorhynchidae) from Algarrobo, Chile, with comments on aspidorhychid paleodistribution in South America. Revista Geologica de Chile, 30:117-127. https://doi.org/10.4067/S071602082003000100008

Bryant, L.J. 1987. Belonostomus (Teleostei: Aspidorhynchidae) from the Late Paleocene of North Dakota. Paleobios, 43:1-3.

Cavin, L. 2002. Effects of the Cretaceous-Tertiary boundary event on bony fishes, p.141-158. In Buffetaut E. and Koeberl C. (eds.), Geological and Biological Effects of Impact Events. Springer-Verlag, Berlin. https://doi.org/10.1007/978-3-642-59388-8_6

Cavin, L. 2008. Palaeobiogeography of Cretaceous bony fishes (Actinista, Dipnoi and Actinopterygii), p. 165-183. In Cavin, L., Longbottom, A., and Richter, M. (eds.), Fishes and the Breakup of Pangaea. Geological Society of London Special Publications, 295. https:// doi.org/10.1144/SP295

Demar, Jr., D.G. and Breithaupt, B.H. 2006. The nonmammalian vertebrate microfossil assemblages of the Mesaverde Formation (Upper Cretaceous, Campanian) of the Wind River and Bighorn basins, Wyoming. Bulletin of the New Mexico Museum of Natural History and Science, 35:33-53.

Ebert, M. 2014. The genus Belonostomus Agassiz, 1834 (Neopterygii, Aspidorhynchiformes) in the Late Jurassic of the Solnhofen Archipelago, with a focus on Belonostomus kochii Münster, 1836 from Ettling (Germany). Archaeopteryx, 32:15-43. 
Estes, R. 1964. Fossil vertebrates from the Late Cretaceous Lance Formation Eastern Wyoming. University of California Publications in the Geological Sciences, 49:1-180.

Espinosa-Arrubarrena, L. and Alvarado-Ortega, J. 2010. Field trip to the Tlayúa quarry. Gonzalez-Rodriguez, K. and Arratia, G. (eds.), Fifth International Meeting of Mesozoic Fishes-Global Diversity and Evolution. Abstract Book \& Field Guides. Pachua, Cinecia al Dia, 19:93-113.

Everhart, M.J. 2009. First occurrence of marine vertebrates in the Early Cretaceous of Kansas: Champion Shell Bed, basal Kiowa Formation. Transactions of the Kansas Academy of Science, 112(3 and 4):201-210. https://doi.org/10.1660/062.112.0408

Felix, J.P. 1891. Versteinerungen aus der mexicanischen Jura- und Kreide-Formation. Palaeontographica, 37:140-194.

Fox, R.C. 1984. Ichthyornis (Aves) from the early Turonian (Late Cretaceous) of Alberta. Canadian Journal of Earth Sciences, 19:118-128. https://doi.org/10.1139/e84-026

Friedman, M. 2009. Ecomorphological selectivity among marine teleost fishes during the endCretaceous extinction. Proceedings of the National Academy of Sciences, 106:5218-5223. https://doi.org/10.1073/pnas.0808468106

Giersch, S., Stiennesbeck, W., and González Gonzáles, A.H. 2010. Pachyrhizodus caninus Cope, 1872 (Teleostei, Crossognathiformes) from the early Turonian of Vallecillo (Mexico). Neues Jahrbuch für Geologie und Paläontologie-Abhandlungen, 258: 219-228. https:// doi.org/10.1127/0077-7749/2010/0099

Gouiric-Cavalli, S., 2015. Jonoichthys challwa gen. et sp. nov., a new Aspidorhynchiform (Osteichthyes, Neopterygii, Teleosteomorpha) from the marine Upper Jurassic sediments of Argentina, with comments about paleobiogeography of Jurassic aspidorhynchids. Comptes Rendus Palevol, 14:291-304. https://doi.org/10.1016/j.crpv.2015.03.007

Heads, M. 2005. Towards a panbiogeography of the seas. Biological Journal of the Linnean Society, 84:675-723. https://doi.org/10.1111/j.1095-8312.2005.00466.x

Kogan, I. and Licht, M. 2013. A Belonostomus tenuirostris (Actinopterygii: Aspidorhynchidae) from the Late Jurassic of Kelheim (southern Germany) preserved with its last meal. Paläontologische Zeitschrift, 87:543-548. https://doi.org/10.1007/s12542-013-0179-z

Lambe, L. M. 1902. New genera and species from the Belly River series (mid-Cretaceous). Contributions to Canadian Paleontology, 3:25-81.

López-Arbarello, A. and Sferco, E. 2018. Neopterygian phylogeny: the merger assay. Royal Society Open Science 5:172337. https://doi.org/10.1098/rsos.172337

Murray, A.M. and Cook, T. 2016. Overview of the Late Cretaceous fishes of the Northern Western Interior Seaway. p. 255-261. In Khosla, A. and Lucas S. G. (eds.), Cretaceous Period: Biotic Diversity and Biogeography. New Mexico Museum of Natural History and Science Bulletin, 71.

Pearson, D.A., Schaefer, T., Johnson, K.R., Nichols, D.J., and Hunter, J.P. 2002. Vertebrate biostratigraphy of the Hell Creek Formation in southwestern North Dakota and northwestern South Dakota. In Hartman, J., Johnson, K.R., and Nichols, D.J. (eds.), The Hell Creek Formation and the Cretaceous-Tertiary Boundary in the northern Great Plains. Geological Society of America Special Paper, 361:145-167. https://doi.org/10.1130/0-8137-2361-2.145

Ping, J.-H., Russell, A.P., and Brinkman, D.B. 2001. Vertebrate microsite assemblages (exclusive of mammals) from the Foremost and Oldman formations of the Judith River Group (Campanian) of Southeastern Alberta. Provincial Museum of Alberta Natural History Occasional Paper No. 25 https://doi.org/10.5962/bhl.title.115853

Prieto-Márquez, A., Erickson, G.M., and Ebersole, J.A. 2016. Anatomy and osteohistology of the basal hadrosaurid dinosaur Eotrachodon from the uppermost Santonian (Cretaceous) of Southern Appalachia. PeerJ, 4:e1872. https://doi.org/10.7717/peerj.1872

Puckett, T.M. 2005. Santonian-Maastrichtian planktonic foraminiferal and ostracode biostratigraphy of the northern Gulf Coastal Plain, USA. Stratigraphy, 2:117-146.

Russell, D.A. 1988. A checklist of North American marine Cretaceous vertebrates including fresh water fishes. Royal Tyrrell Museum of Paleontology Occasional Paper, 4:58.

Schein, J.P. and Lewis, R.D. 2007. Actinopterygian fishes from Upper Cretaceous rocks in Alabama, with emphasis on the teleostean genus Enchodus. Paludicola, 6:41-86.

Schultze, H. -P., Stewart, J.D., Neuner, A. M., and Coldiron, R.W. 1982. Type and figured specimens of fossil vertebrates in the collection of the University of Kansas Museum of Natural History part I. Fossil fishes. University of Kansas Museum of Natural History Miscellaneous Publications 73:1-53. https://doi.org/10.5962/bhl.title.6367 
Scott, R.W., Benson, D.G., Morin R.W., Shaffer, B.L., and Oboh-lkuenobe, F.E. 2003. Integrated Albian-lower Cenomanian chronostratigraphy standard, Trinity River section, Texas. US Gulf Coast Cretaceous stratigraphy and paleoecology: Gulf Coast Section, Society of Economic Paleontologists and Mineralogists, Bob F. Perkins Memorial Conference 23:277-334.

Shimada, K. and Fielitz, C. 2006. Annotated Checklist of fossil fishes from the Smoky Hill Chalk of the Niobrara Chalk (Upper Cretaceous) in Kansas. Bulletin of the New Mexico Museum of Natural History, 35:193-213.

Thurmond, J. T. 1974. Lower vertebrate faunas of the Trinity Division in North-Central Texas. Geoscience and Man, 8:103-129.

Wainwright, P. C. and Barton, B.A. 1995. Predicting patterns of prey use from morphology of fishes. Environmental Biology of Fishes, 44:97-113. https://doi.org/10.1007/bf00005909

Whetstone, K. 1978. Belonostomus sp. (Teleostei, Aspidorhynchidae) from the Upper Cretaceous Tombigbee Sand of Alabama. University of Kansas Paleontological Contributions 89:17-19.

Woodward, A.S. 1985. Catalogue of the Fossil Fishes in the British Museum (Natural History) Volume 3. British Museum, London. 